\title{
Tantangan dan Permasalahan Penegakan Hukum Tindak Pidana Korupsi di Indonesia
}

\author{
Yenni Wiranti1雨, Ridwan Arifin2 \\ Fakultas Hukum Universitas Negeri Semarang \\ E-mail: yenniwiranti15@gmail.com
}

\begin{abstract}
Corruption is an extraordinary crime. It grows in the human body because man's eternal nature is greed. Corruption is an act committed with the intention of obtaining several benefits that is contrary to official duties and other truths. The Corruption Law is regulated in Law Number 31 Year 1999. It is understandable if corruption is so difficult to eradicate, partly because the approach used is still partial, whereas the handling needed is a multidimensional approach. The wide enough social and power gap in the structure of society also influences the opening of opportunities for corruption, which in turn contributes greatly to the culture of corruption.

Keywords: Corruption, Eradication, Causes of Corruption, Law Enforcement

Abstrak

Korupsi adalah kejahatan yang sangat luar biasa. Ia tumbuh dalam tubuh manusia karena sifat kekal manusia adalah keserakahan. Tindak korupsi suatu perbuatan yang dilakukan dengan sebuah maksud untuk mendapatkan beberapa keuntungan yang bertentangan dengan tugas resmi dan kebenarankebenaran lainnya. Undang-Undang Korupsi diatur dalam UU Nomor 31 Tahun 1999. Dapat dipahami apabila korupsi begitu sulit diberantas, antara lain disebabkan oleh pendekatan yang dipergunakan masih bersifat parsial, padahal penanganan yang diperlukan adalah pendekatan multidimensional. Kesenjangan sosial dan kekuasaan yang cukup lebar dalam struktur masyarakat, juga turut mempengaruhi terbukanya peluang melakukan korupsi yang pada gilirannya memberi kontribusi besar bagi pembudayaan korupsi.
\end{abstract}

Kata kunci: Korupsi, Pemberantasan, Penyebab Korupsi, Penegakan Hukum

Copyright@2020KosmikHukum. All rights reserved.

\section{Pendahuluan}

Berbagai upaya pemberantasan korupsi terus gencar dilakukan seiring dengan terus berkembangnya motif pada tindak pidana ini. Selepas tergabung suatu misi Peraturan Mahkamah Agung Nomor 13 tahun 2016 perihal Tata Cara Penanganan Perkara Tipikor, dalam 2017, Komisi Pemberantasan Korupsi meninggikan identitas satu masalah oleh subjek hukum korporasi ke jenjang penyelusuran. Kasus PT Darajat Geothermal Indonesia misalnya, yang sudah mengubah identitas menjadi PT NIKE dengan yang bersangkutan dituduhkan berkewajiban terhadap semua kompensasi keuangan negara kira-kira 25 miliar rupiah dalam suatu kegiatan perencanaan membangun RS pendidikan khusus penyakit infeksi serta pariwisata Universitas Udayana Tahun 2009-2010 bernilai kira-kira 138 miliar rupiah. Disamping semua itu, bermaksud guna menambah akibat jera untuk tersangka penggelapam korupsi juga memberikan jalan dalam mengembalikan keuangan negara, KPK membangun kerja bersama dengan rekan kerja terkait merencana suatu kegiatan modul teknisi penindakan kasus Tindak Pidana Pencucian Uang serta perbaikan aset di dalam pasar modal.

Model yang dikehendaki dalam tuntunan untuk para penegak hukum sebagai jalur penanganan masalah TPPU serta perbaikan aset hanya untuk dalam pasar modal. Wawasan berbeda dalam penegekan hukum, Komisi Pemberantasan Korupsi beserta MA, membuat 
Kosmik Hukum Vol. 20 No. 1 (2020): 45-55

E-ISSN: 2655-9242 | P-ISSN: 1411-9781

DOI: 10.30595/kosmikhukum.v20i1. 3822

analisis penataan subtansi menggunakan output anjuran penuntasan perkara prosedur subtansi tuntutan. Tahun 2017, Komisi Pemberantasan Korupsi menjalankan (114) suatu penyidikan, (118) pemeriksaan, serta (94) penuntutan, baik perkara terkini ataupun sisa penindakan kasus tahun sebelumnya. Dan melaksanakan eksekusi kepada 76 vonis pengadilan yang sudah menjadi tersangka tetap. Kurang lebih Rp 188 milyar sudah dicantumkan didalam kas negara berbentuk Pendapatan Nasional Bukan Pajak bermula penyelesaian kasus.Terpadu didalam pada perolehan kegiatan pelelangan benda sitaan dan rampasan atas kasus tipikor maupun TPPU sejumlah 82 miliar rupiah.

Komisi Pemberantasan Korupsi melewati sektor pencarian aset//barang, pengelolaan barang bukti dan sitaan (Labuksi) berupaya demi memulihkan aset (aset recovery) dari kasus korupsi dan TPPU. Tidak cuman dengan pelelangan bersama DJKN, eksekusi sitaan rampasan dengan dibuatnya penerapan identitas dan hibah. Teknik eksekusi dipakai lantaran terdesak suatu keperluan Perpu atau Perda dalam suatu benda tarikan negara baik benda yang aktif ataupun non aktif dalam suatu kegiatan pemerintah. Di tahun 2017 Komisi Pemberantasan Korupsi sudah memberikan barang tarikan sebanyak 88,6 miliar rupiah, yang berbentuk tanah/daratan dan bangunan/gedung bernilai Rp 49 milyar di Surakarta terhadap Pemerintah Kota Surakarta untuk dipakai sebagai Musium Batik, tanah/daratan dan bangunan/gedung bernilai Rp 24,5 milyar terhadap ANRI (Arsip Nasional Republik Indonesia) guna dibuat pusat arsip pemberantasan korupsi, tanah/daratan dan bangunan/gedung bernilai Rp 2,9 milyar tepatnya di Karawang Barat untuk Badan Pusat Statistik guna dibuat untuk rumah dinas dan pelebaran kantor, wisma penginapan serta barang-barangnya yang bernilai Rp 11,9 milyar bagi Kementrian Keuangan dan kendaraan dinas untuk Rupbasan Pekanbaru. Terdeteksi dari suatu masalah, Tipikor yang sering ditemukan ialah penyuapan dengan 93 kasus, diikuti penyediaan barang/jasa sejumlah 15 kasus, beserta TPPU sejumlah lima kasus. Beberapa keterangan penyelesaian kasus sesuai jenjang pangkat, membuka ada 43 kasus yang mengikutsertakan pejabat/anggota eselon 1 sampai 4 dan 27 kasus mengikutsertakan swasta beserta 20 kasus menyeret pejabat/anggota Dewan Perwakilan Rakyat/Dewan Perwakilan Rakyat Daerah. Sementara itu, diperoleh 12 kaus lainnya yang menyeret Bupati Walikota beserta para wakilnya. Bagian dari perkara yang ditangani tersebut, terdapat 19 kasus yang merupakan hasil tangkap tangan. Hasil dari tangkap tangan di tahun 2017 ini lebih banyak dari tahun-tahun sebelumnya dan itu adalah yang paling terbanyak selama Komisi Pemberantasan Korupsi didirikan.

Dari 19 perkara tersebut, Komisi Pemberantasan Korupsi sudah memvonis 72 orang sebagai pelaku dengan berbagai macam identitas pelaku, seperti para anggota/aparat penegak hukum, anggota/pejabat legislatif hingga kepala daerah. Semua itu belum termasuk pelaku yang divonis selannjutnya dari keputusan pengembangan perkara. Pada suatu kunjungan Koordinasi dan Supervisi Bidang Penindakan, Komisi Pemberantasan Korupsi telah melaksanakan penyidikan sejumlah 183 penindakan kasus dari 80 kasus yang akan dicapai tahun 2017. Sementara supervisi dilakukan terhadap 289 perkara dari 164 perkara yang direncanakan.

Dalam kegiatan ini, Komisi Pemberantasan Korupsi berusaha memajukan penanganan perkara oleh penegak hukum lainnya dengan memberikan jalan untuk mengajukan perbedaan pendapat dan masalah lainnya lewat sebutan tajuk bersama, melayani ahli terrtera didalamnya terpaut taksiran defisit kerugian negara. Sementara itu, semenjak dikeluarkan tahun sebelumnya pelaporan Surat Pemberitahuan Dimulainya Penyidikan online (e-SPDP) untuk sinergi dalam penanganan perkara korupsi diantara lembaga penegak hukum lainnya, kini (eSPDP) sudah diimplementasikan di 8 intstansi, yaitu Polda Jawa Timur, Kejati Jawa Timur, Polda Jawa Barat, Kejati Jawa Barat, Polda Sumatera Utara, Bareskrim Polri dan Jampidsus Kejaksaan RI. Di tahun 2017, Komisi Pemberantasan Korupsi sudah mendapat pemberitahuan penyidikan tipikor dari aparat penegak hukum lainnya, yaitu sejumlah 797 SPDP dari kejaksaan, dan 350 SPDP dari Kepolisian. Yang umum dilakukan, Komisi Pemberantasan Korupsi bekerja keras memberi kualitas dalam pembasmian perkara dengan mengadakan 
Pelatihan Bersama Aparat Penegak Hukum yang pada tahun 2017 diadakan di Banten, Sulawesi Tenggara dan Sumatera Selatan. Pada kegiatan ini, diikuti oleh 501 aparat penegak hukum dari Kepolisian, Kejaksaan, Penyidik TNI dan OJK, beserta auditor pada Badan Pemeriksa Keuangan, Badan Pengawas Keuangan Pembangunan dan Pusat Pelaporan dan Analisis Transaksi Keuangan. Selama tahun 2017 Komisi Pemberantasan Korupsi sudah menandatangani sejumlah Nota Kesepahaman (MoU)dengan kementrian beserta instansi di luar instansi penegak hukum, yaitu dengan Kementrian Pendidikan dan Kebudayaan, ANRI dan Komisi Aparatur Sipil Negara dalam rangka pemberantasan korupsi.

Sementara itu, dalam rangka mengokohkan fungsi pengawasan intern kementrian dan lembaga (Aparat Pengawas Intern Pemerintah), Komisi Pemberantasan Korupsi bersamaan dengan 17 kementrian dan lembaga menandatangani MoU berkenaan pembangunan koneksitas whistleblowing system. Bukan cuman dengan kementrian lembaga Komisi Pemberantasan Korupsi membangun kerjasama dengan sejumlah 33 perguruan tinggi dalam memajukan tarnsparasi peradilan. Terdapat 217 perkara. 182 perkara tahun 2017 dan 35 perkara dari tahun sebelumnya yang direcord bersama tim perecordan persidangan dari yang meliputi perkara yang ditangani oleh Komisi Pemberantasan Korupsi, Kejaksaan, perkara Pra-Peradilan perkara Peninjauan Kembali (PK), dan perkara pada Pengadilan Tata Usaha Negara. Pengunaan hasil record persidangan ini dipergunakan oleh pengadilan tindak pidana korupsi, kampus dan CSO (Civil Society Organization) sebagai bahan pembelajaran/pendidikan dan eksaminasi putusan. Untuk mencapai peradilan bersih dan korupsi, Komisi Pemberantasan Korupsi pun melakukan penyelarasan dengan jaringan pemantau peradilan didaerah dengan mengkaitkan Penghubung Komisi Yudisial dan CSO di 5 kota antara lain, Mataram, Medan, Makasar, Manado dan Samarinda. Kerja sama bersama perguruan tinggi tidak bisa terlepas dari pentingnya kampus selaku sebagai pusat pemberantasan korupsi.

Sepanjang tahun 2017, Komisi Pemberantasan Korupsi berhasil mendorong terbentuknya pusat kajian antikorupsi di beberapa kampus seperti Universitas Atma Jaya, Universitas Muhammadiyah Jogjakarta, Universitas Bengkulu, Universitas Negeri Padang, dan Universitas Sam Ratulangi Manado. Selain itu, Komisi Pemberantasan Korupsi pun melaksanakan hal yang sama terhadap setidaknya 15 perguruan tinggi diseluruh Indonesia. Tujuannya, terwujudnya konsolidasi gerakan bersama antara perguruan tinggi dan masyarakat sipil dalam usaha pemberantasan korupsi di Indonesia. Didalam sektor perguruan tinggi, pasca terbit Peraturan Mahkamah Agung No 13 tahun 2016 Komisi Pemberantasan Korupsi dan MA, membentuk Forum Komunikasi Penegak Hukum di sekitar Sumatera, Kalimamntan, Sulawesi, Jabodetabek dan Bali dalam upaya mendiseminasikan dan meningkatkan kapasitas penegak hukum, maupun penyidik, penuntut, dan hakim terkait pemidanaan korporasi. Secara umum, untuk memajukan penguatan sistem kedisiplinan disektor swasta dalam upaya menghindari pemidanaan korporasi, Komisi Pemberantasan Korupsi pun menandatangani MoU dengan KADIN (Kamar Dagang dan Industri Indonesia).

Selain melalui lembaga/instasni nasional, pembinaan kerjasama dengan lembaga lain diluar negeri tak kalah penting, baik dalam mendukung kegiatan penindakan maupun pencegahan serta peningkatan kapasitas sumber daya manusia. Komisi Pemberantasan Korupsi menandatangani sejumlah MoU strategis yaitu dengan Attorney General's Departement (AGD) Australia, Ministry of Justice Investigation Bureau (MJIB) Taiwan dan Instance Nationale de Lutte Conter la Coruption (INLUCC) Turnisia. Ruang lingkup kerjasama antara lain berhubungan dengan pertukaran informasi dan teknologi, sharing best practices, capacity building serta bantuan dibidang pencegahan dan bantuan penegakan hukum. Sebagian penerapan kerjasama dengan mitra kerjasama luar negeri ialah pertukaran informasi dan data, baik bersifat formal antara lain melalui Mutual Legal Assitance (MLA) maupun bersifat informal. Selama tahun 2017, Komisi Pemberantasan Korupsi pernah memberi fasilitas lebih dari 13 permohonan bantuan informasi dan data dari negara lain, 51 permohonan bantuan infromasi kepada negara lain dan 4 permintaan MLA. Demi mewujudkan dukungan internasional dan implementasi komitmen global, Komisi Pemberantasan Korupsi 
Kosmik Hukum Vol. 20 No. 1 (2020): 45-55

E-ISSN: 2655-9242 | P-ISSN: 1411-9781

DOI: 10.30595/kosmikhukum.v20i1. 3822

bersangkutan didalam berbagai forum internasional seperti UNCAC, G20, APEC, IACA dan SEA-PAC.

Sebagai salah satu negara peratifikasi Konvensi PBB Anti Korupsi (UNCAC), pada tahun 2017 ini Indonesia menjalani prosedur review putaran kedua yang menyajikan implementasi UNCAC Bab 2 tentang Pencegahan dan Bab 5 tentang pemulihan aset. Komisi Pemberantasan Korupsi selaku focal point didalam proses review, mengkoordinasikan 24 kementrian dan lembaga dalam pengumpulan informasi dan penyusunan jawaban atas self-assesment checklist serta menjalankan review pada Oktokber 2017. Sementara itu dalam upaya mewujudkan pendapat penting dalam G-20 Anti-Corruption Working Group (ACWG) Komisi Pemberantasan Korupsi bersamaan dengan stakeholder terkait melaksanakan kajian transparansi Beneficial Ownership (BO) yang hendak mendefinisikan anjuran mulai dari sebagian perspektif apalagi kebijakan dan regulasi nasional sehingga memberikan faedah terhadap penegak hukum.

Kemudian, pembaharuan hubungan kerjasama diwilayah multilateral dilaksanakan melewati bermacam kegiatan, sebagaimana aktif dalam Implementation Review Group (IRG), Pertemuan Conference of States Parties United Nations Convention Againts Corruption (COSO UNCAC), Anti-Corruption Working Group (ACWG) I, II, dan III, Senior Official Meeting 1 AntiCorruption and Transparency Working Group (ACTWG) APEC dan SOM ACTWG III. Saat mewujudkan kenaikan kualitas penegak hukum, Komisi Pemberantasan Korupsi berpedoman pada wadah Internasional seperti Anti-Corruption Academy (IACA) di Mesir. Didalam wilayah Asia Tenggara, Komisi Pemberantasan Korupsi mempunyai tanggungjawab bersama berbagai lembaga/instansi anti korupsi di Asia Tenggara melewati forum South East Asia Parties Againts Corruption (SEA-PAC).1

\section{Metodologi Penelitian}

Tulisan ini lebih fokus kepada kajian terhadap upaya-upaya penegakan hukum dalam pemberantasan dan penegakan hukum korupsi di Indonesia. penelitian ini menggunakan kajian yuridis normatif dimana penulis hanya mengkaji berbagai aturan perundang-undangan, melihat celah dan kelemahan undang-undang tersebut. Kasus-kasus dalam tulisan ini didapatkan melalui kasus-kasus yang diperoleh baik itu melalui media massa, laporan tahunan, maupun sumber cetak atau online lainnya.

\section{Hasil dan Pembahasan}

\section{Pengertian Tindak Pidana Korupsi}

Kamus Umum Bahasa Indonesia yang di tata oleh Poerwadarminta (1976: 524), pengertian korupsi ialah; "perbuatan yang buruk seperti penggelapan uang, penerimaan uang sogokan dan sebagainya". Yang karena ruang lingkupnya sangat luas, maka pengertian korupsi disederhanakan yang secara umum menjadi"perbuatan buruk dan dapat disuap". David H. Bayley mendefinisikan korupsi sebagai: "Perangsang (seorang pejabat pemerintah dan swasta) berdasarkan itikad buruk (seperti misalnya, suapan) agar ia melakukan pelanggaran kewajibannya". Sedangkan sogokan didefinisikan oleh David. H. Bayley sebagai: "Hadiah, penghargaan, pemberian atau kesitimewaan yang dianugerahkan atau dijanjikan, dengan tujuan merusak pertimbangan atau tingkah laku, terutama seorang dari dalam kedudukan terpercaya (sebagai pejabat pemerintah atau swasta)".

Pengertian korupsi menurut hukum Indonesia, tidak dijelaskan dalam pasal pertama UU Korupsi seperti undang-undang lainnya. Dengan demikian, untuk mengetahui apa yang dimaksud dengan korupsi, harus dilihat dalam rumusan pasal-pasal UU Korupsi, yaitu sekitar

Capaian dan Kinerja KPK di Tahun 2017 
13 pasal yang mengaturnya serta terdapat tiga puluh jenis tindakan yang dapat dikategorikan sebagai korupsi.2

Pengertian korupsi menurut masyarakat awam khususnya adalah suatu perbuatan mengambil uang negara agar mendapat keuntungan untuk diri sendiri. Pengertian Tindak Pidana Korupsi sendiri ialah kegiatan yang dilakukan untuk memperkaya diri sendiri atau kelompok dimana kegiatan itu melanggar hukum karena telah merugikan bangsa dan negara.3

Korupsi telah diidentifikasi sebagai musuh terbesar bagi perkembangan dan kemajuan bangsa mana pun. Di Nigeria, korupsi adalah seekor belalang yang telah memakan falora masyarakat kita di setiap tingkatan. Memiliki menyebabkan keterlambatan dan kelalaian dalam infrastruktur pemerintah dan masyarakat luas. Itu layak untuk dicatat bahwa korupsi telah bertanggung jawab atas ketidakstabilan pemerintah berturut-turut sejak republik pertama hingga saat ini.4

Korupsi adalah fenomena yang kompleks dan multifaset dengan banyak penyebab dan efek, karena mengambil berbagai bentuk dan fungsi dalam konteks yang berbeda. Itu fenomena korupsi berkisar dari satu tindakan pembayaran yang bertentangan dengan hukum untuk suatu malfungsi endemik dari sistem politik dan ekonomi. Masalahnya korupsi telah dilihat baik sebagai masalah struktural politik atau ekonomi, atau sebagai masalah moral budaya dan individu. Definisi korupsi karenanya berkisar dari istilah luas "penyalahgunaan kekuatan publik" dan "kerusakan moral" hingga ketat definisi hukum korupsi sebagai tindakan suap yang melibatkan pegawai negeri dan atransfer sumber daya nyata. 5

Tindak pidana korupsi merupakan masalah yang sangat serius, karena tindak pidana korupsi dapat membahayakan stabilitas dan keamanan negara dan masyarakatnya, membahayakan pembangunan sosial dan ekonomi masyarakat, politik bahkan dapat pula merusak nilai-nilai demokrasi serta moralitas bangsa karena dapat berdampak membudayanya tindak pidana korupsi tersebut.6

\section{Korupsi dalam Undang-Undang Nomor 31 Tahun 1999}

Korupsi merugikan keuangan negara atau ekonomi negara dan menghambat pembangunan nasional, karenanya harus diberantas dalam konteks menciptakan persamaan dan masyarakat sejahtera berdasarkan Pancasila dan UUD 1945.7

UU Korupsi Tahun 1999 menggantikan berlakunya UU Korupsi Tahun 1971 dan disahkan berlakunya pada tanggal 16 Agustus 1999, tetapi pada saat awal diberlakukan sempat menimbulkan masalah dalam penerapannya, akibat ketentuan Pasal 44 UU Korupsi Tahun 1999 yang berbunyi bahwa pada saat mulai berlakunya undang-undang ini, maka UndangUndang Nomor 3 Tahun 1971 tentang Pemberantasan Tindak Pidana Korupsi (Lembaran Negara Tahun 1971 Nomor 19, tambahan Lembaran Negara Nomor 2958), dinyatakan tidak berlaku lagi. Adapun perbuatan yang dilarang sebagai korupsi serta subjek pembuat korupsi dalam UU Korupsi Tahun 1999 pada pada hakikatnya tidak jauh berbeda dengan perbuatan yang dilarang dalam UU Korupsi Tahun 1971.

\footnotetext{
Mas, Marwan. Pemberantasan Tindak Pidana Korupsi, Cet 1. Bogor: Penerbit Ghalia Indonesia. 2014. Hlm, 5-8. http://digilib.unila.ac.id/525/7/BAB\%20II.pdf diakses Sabtu, 9 Desember 2018 12:20 WIB.

Ofoegbu Grace N, James Isaiah Ekele, "The Role of Chartered Accountants in Eradicating Corruption in Nigeria", British Journal of Humanities and Social Sciences, April 2018, Vol. 20 No. 1, hlm. 46 (45-50), online pada http://www.ajournal.co.uk/HSpdfs/HSvolume20(1)/HSVol.20\%20(1)\%20Article\%205.pdf

5 Research on Corruption A policy oriented survey, http://www.icgg.org/downloads/contribution07_andvig.pdf Diakses, Sabtu 09 Desember 2018 12:49 WIB.

6 Djaja, Ermansyah. Memberantas Korupsi Bersama KPK Kajian Yuridis Normatif UU Nomor 31 Tahun 1999 juncto UU Nomor 20 Tahun 2001 Versi UU Nomor 30 Tahun 2002. Jakarta: Sinar Grafika. hlm, 2.

7 Undang-Undang Nomor 31 Tahun 1999 tentang Pemberantasan Tindak Pidana Korupsi.
} 
Kosmik Hukum Vol. 20 No. 1 (2020): 45-55

E-ISSN: 2655-9242 | P-ISSN: 1411-9781

DOI: 10.30595/kosmikhukum.v20i1. 3822

a. Pasal 2 Ayat (1): Setiap orang yang secara melawan hukum melukan perbuatan memperkaya diri sendiri atau orang lain atau suatu korporasi yang dapat merugikan keuangan negara atau perekonomian negara.

b. Pasal 3: Setiap orang dengan tujuan menguntungkan diri sendiri atau orang lain atau suatu korporasi, menyalahgunakan kewenangan, kesempatan atau sarana yang ada padanya karena jabatan atau kedudukan yang dapat merugikan keuangan negara atau perekonomian negara.

c. Pasal 5: Setiap orang yang melakukan tindak pidana sebagaimana dimaksud dalam Pasal 209 KUHPidana (memberi atau menjanjikan sesuatu kepada seseorang pejabat dengan maksud agar berbuat atau tidak berbuat dalam jabatannya, atau bertentangan dengan jabatannya).

d. Pasal 6: Setiap orang yang melakukan tindak pidana sebagaimana dimaksud dalam Pasal 210 KUHPidana (memberi atau menjanjikan sesuatu kepada seorang hakim untuk mempengaruhi kekuasaanya).

e. Pasal 7: Setiap orang yang melakukan tindak pidana sebagaimana dimaksud dalam Pasal 387 KUHPidana (pemborong yang melakukan perbuatan tipu yang dapat mendatangkan bahaya bagi keselamatan orang atau benda atau negara dalam keadaan perang, dan pengawas yang membiarkan perbuatan tipu itu), atau Pasal 388 KUHPidana (leveransir tentara yang melakukan perbuatan tipu dapat mendatangkan bahaya bagi keselamatan negara pada waktu perang).

f. Pasal 8: Setiap orang yang melakukan tindak pidana sebagaimana dimaksud dalam Pasal 415 KUHPidana (penggelapan oleh seorang pejabat atau orang lain yang menjalankan suatu jabatan umum.

g. Pasal 9: Setiap orang yang melakukan tindak pidana sebagaimana dimaksud dalam Pasal 416 KUHPidana (pejabat atau orang lain yang menjalankan suatu jabatan umum yang sengaja membuat secara palsu atau memalsukan buku-buku atau daftar khusus untuk pemeriksaan administrasi).

h. Pasal 10: Setiap orang yang melakukan tindak pidana sebagaimana dimaksud dalam Pasal 417 KUHPidana (pejabat atau orang lain yang menjalankan suatu jabatan umum yang sengaja menggelapkan, menghancurkan, merusak, atau membikin tidak dapat dipakai barang-barang sebagai pembuktian seperti akta-akta, surat-surat atau daftardaftar yang dikuasainya karena jabatannya).

i. Pasal 11: Setiap orang yang melakukan tindak pidana sebagaimana dimaksud dalam Pasal 418 KUHPidana (pejabat yang menerima hadiah atau janji atas kekuasaan/kewenangan yang berhubungan dengan jabatannya).

j. Pasal 12: Setiap orang yang melakukan tindak pidana sebagimana dimaksud dalam Pasal 419, Pasal 420, Pasal 423, Pasal 425, atau Pasal 435 KUHPidana).

k. Pasal 13: Setiap orang yang memberi hadiah atau janji kepada pegawai negeri dengan mengingat kekuasaan atau wewenang yang melekat pada jabatan atau kedudukannya, atau oleh pemberi hadiah atau janji dianggap melekat pada jabatan atau kedudukan tersebut.

1. Pasal 14: Setiap orang yang melanggar ketentuan undang-undang yang secara tegas menyatakan bahwa pelanggaran terhadap ketentuan undang-undang tersebut sebagai tindak pidana korupsi.

m. Pasal 15: Setiap orang yang melakukan percobaan, pembantuan, atau permufakatan jahat untuk melakukan tindak pidana korupsi. 
n. Pasal 16: Setiap orang diluar wilayah negara Republik Indonesia memberikan bantuan, kesempatan, atau keterangan untuk terjadinya tindak pidana korupsi.

o. Pasal 21 (tindak pidana lain yang berkaitan dengan korupsi) : Setiap orang yang dengan sengaja mencegah, merintangi, atau menggagalkan secara langsung atau tidak langsung penyidikan, penuntutan, dan pemeriksaan disidang pengadilan terhadap tersangaka atau terdakwa ataupun para saksi dalam perkara korupsi.

p. Pasal 22 (tindak pidana lain yang berkaitan dengan korupsi): Setiap orang sebagaimana dimaksud Pasal 28, Pasal 29, Pasal 35, dan Pasal 36, sengaja tidak memberi keterangan atau memberi keterangan yang tidak benar.

q. Pasal 24 (tindak pidana lain yang berkaitan dengan korupsi): saksi yang tidak memenuhi ketentuan Pasal 31 undang-undang ini.

Beberapa kelebihan pengaturan atau materi UU Korupsi Tahun 1999 dibandingkan dengan UU Korupsi Tahun 1971 adalah sebagai berikut:

a. Rumusan atau sifat "melawan hukum"dalam Pasal 2 Ayat (1) bukan hanya mencakup perbuatan melawan hukum dalam arti formil, melainkan juga melawan hukum dalam arti materiil yaitu "meskipun perbuatan tersebut tidak diatur dalam peraturan perundang-undangan, tetapi perbuatan tersebut dianggap tercela karena tidak sesuai dengan rasa keadilan atau norma-norma kehidupan sosial dalam masyarakat, maka perbuatan tersebut dapat dipidana" (Penjelasan Pasal 2 Ayat 1).

b. Rumusan tindak pidana korupsi bersifat "delik formil", yaitu delik (tindakan pidana korupsi) dianggap telah terpenuhi apabila unsur-unsur perbuatan telah terpenuhi, tanpa memperhitungkan akibat dari perbuatan itu.

c. Mengatur "pemberatan pidana" (Pasal 2 Ayat (2)) dalam bentuk hukuman mati bagi seseorang yang melakukan korupsi sebagaimana dimaksud dalam Pasal 2 Ayat (1), jika dilakukan dalam keadaan tertentu.

d. Mengatur ancaman pidana "minimum khusus", yaitu ancaman pidana penjara minimal: mulai dari 1-4 tahun. Ancaman pidana minimal 4 tahun apabila melanggar Pasal 1 Ayat (1).

e. Mengatur ancaman "pidana denda" yang lebih tinggi, dan ancaman pidana penjara bagi "terpidana korupsi yang tidak dapat membayar pidana tambahan berupa uang pengganti kerugian negara (Pasal 17 dan 18).

f. Jika terpidana tidak membayar uang pengganti sebagaimana dimaksud dalam Pasal 18 Ayat (1) huruf-b UU Korupsi Tahun 1999 dalam jangka waktu paling lama satu bulan sesudah putusan pengadilan yang telah memperoleh kekuatan hukum tetap, maka harta bendanya dapat disita oleh jaksa dan dilelang untuk menutupi uang pengganti tersebut (Pasal 18 Ayat (2) UU Korupsi Tahun 1999).

g. Apabila tersangka meninggal dunia dalam proses penyidikan (Pasal 33) atau terdakwa meninggal dunia dalam proses pengadilan (Pasal 34), sedangkan secara nyata telah ada kerugian negara, maka dapat dilakukan gugatan perdata terhadap ahli waris tersangka, yang dilakukan oleh Jaksa Pengacara Negara.

h. Dalam Pasal 4 UU Korupsi Tahun 1999 menetapkan bahwa pengembalian kerugian keuangan negara atau perekonomian negara tidak menghapus dipidananya terdakwa, jika melanggar ketentuan Pasal 2 dan Pasal 3 UU Korupsi Tahun 1999.

i. Terdakwa wajib memberikan keterangan atas harta bendanya, istri atau suami, anak, dan harta benda setiap orang dalam korporasi yang diduga mempunyai hubungan dengan perkara bersangkutan (Pasal 37). Tetapi ketentuan ini tidak menentukan 
Kosmik Hukum Vol. 20 No. 1 (2020): 45-55

E-ISSN: 2655-9242 | P-ISSN: 1411-9781

DOI: 10.30595/kosmikhukum.v20i1. 3822

"ancaman pidana" apabila terdakwa tidak memberikan keterangan yang sebenarnya (berbohong) terhadap keberadaan harta benda yang ditanyakan itu.

Dalam Putusan ini pengaruh pengembalian keruangian keuangan Negara dalam tindak pidana korupsi dalam hal ganti rugi tidak berpengaruh, sedangkandalam uang Pengganti, Denda dan Pidana penjaruh berpengaruh. Bentuk pertanggungjawaban pidana terhadap terhadap terdakwa, Berdasarkan Undang-Undang Nomor 31 Tahun 1999 Juncto Undang-Undang Nomor 20 Tahun 200114 tentang Pemberantasan Tindak Pidana Korupsi Pasal 3, Pasal 4 dan Pasal 18 ayat 1(b) ayat 2 dan 3, dapat dikenakan pidana penjara, denda dan uang pengganti.8

\section{Penyebab dan Pemberantasan Korupsi}

Ada yang mengatakan bahwa upaya yang paling tepat untuk memberantas korupsi adalah menghukum seberat-beratnya pelaku korupsi. Dengan demikian, bidang hukum khususnya hukum pidana akan dianggap sebagai jawaban yang paling tepat untuk memberantas korupsi. Kita bahkan memiliki sebuah lembaga independen yang bernama Komisi Pemberantasan Korupsi (KPK) yang kesemuanya dibentuk salah satunya untuk memberantas korupsi. Ada pula pendapat yang mengatakan bahwa bekal pendidikan (termasuk Pendidikan Agama) memegang peranan yang sangat penting untuk mencegah korupsi. Ada yang mengatakan bahwa untuk memberantas korupsi, sistem dan lembaga pemerintahan serta lembaga-lembaga negara harus direformasi.9

Upaya pemerintah dilaksanakan melalui berbagai kebijakan berupa peraturan perundang-undangan dari yang tertinggi yaitu Undang-Undang Dasar 1945 sampai dengan Undang-Undang tentang Komisi Pemberantasan Tindak Pidana Korupsi. Selain itu, pemerintah juga membentuk komisi-komisi yang berhubungan langsung dengan pencegahan dan pemberantasan tindak pidana korupsi seperti Komisi Pemeriksa Kekayaan Penyelenggara Negara (KPKPN) dan Komisi Pemberantasan Korupsi (KPK). Upaya pencegahan praktek korupsi juga dilakukan di lingkungan eksekutif atau penyelenggara negara, dimana masing-masing instansi memiliki Internal Control Unit (unit pengawas dan pengendali dalam instansi) yang berupa inspektorat.10

Apabila dilihat dari segi si pelaku korupsi, sebab-sebab dia melakukan korupsi dapat berupa dorongan dari dalam dirinya, yang dapat pula dikatakan sebagai keinginan, niat, atau kesadarannya untuk melakukan. Sebab-sebab seseorang terdorong untuk melakukan korupsi antara lain sebagai berikut:

a. Penyebab korupsi

1) Sifat tamak dan keserakahan11

2) Ketimpangan penghasilan sesama pegawai negeri/pejabat negara

3) Ketimpangan penghasilan tersebut menimbulkan rasa cemburu yang luar biasa, yang salah satunya berdampak kepada perbuatan korupsi yang dilakukannya.

4) Gaya hidup konsumtif

5) Kurangnya gaji atau pendapatan pegawai negeri dibandingkan dengan kebutuhan yang makin meningkat.12

6) Kurang adanya keteladanan dan kepemimpinan 13

Dwi Septa Mulyadi, https://edoc.site/jurnal-awan-pdf-free.html Diakses Sabtu, 09 Desember 2018 19:07 WIB. http:/ /akperrsdustira.ac.id/wp-content/uploads/2017/07/Buku-Pendidikan-Anti-Korupsi-untuk-PerguruanTinggi-2017-bagian-2-.pdf Diakses Sabtu, 08 Desember 2018 19:20 WIB.

10 Strategi Pemberantasan Korupsi Oleh Yogi Suwarno dan Deny Junanto (Ketua Tim Peneliti) A. Rina Herawati, Widhi Novianto, Dadan Sidqul Anwar dan Evy Trisulo (Anggota Tim Peneliti).

11 http://eprints.walisongo.ac.id/3925/3/104211009_Bab2.pdf Diakses Sabtu, 08 Desember 2018 21:25 WIB.

12 https://idtesis.com/faktor-penyebab-korupsi/

13 https://akademik.ugm.ac.id/2017/wpcontent/uploads/2016/12/2013_makalah_kuliah_perdana_pascasarjana_ ugm.pdf Diakses Sabtu, 09 Desember 13:17 WIB. 
7) Dalam organisasi, pimpinan akan menjadi panutan dari setiap anggota pada organisasi tersebut. Apabila pimpinannya mencontohkan gaya hidup yang bersih dengan tingkat kehidupan ekonomi yang wajar, maka anggota-anggota organisasi tersebut akan cenderung untuk bergaya hidup yang sama. Sebaliknya, apabila pimpinan organisasi gaya hidupnya berlebihan, maka anggotanya akan mengikuti. Apabila tidak mampu menopang biaya hidup yang berlebihan tersebut, maka akan berusaha untuk melakukan berbagai hal termasuk korupsi.

8) Moral yang lemah

9) Kebutuhan hidup yang mendesak

10) Lemahnya penegakan hukum

11) Faktor politik

12) Budaya organisasi pemerintah 14

b. Pemberantasan korupsi

1) Penegakkan hukum oleh komisi pemberantasan korupsi

2) Tindakan tegas dan tanpa diskriminasi

3) Komitmen pimpinan penyelenggaraan negara

4) Peningkatan peran serta masyarakat

5) Pengembangan Whistle Blower (pelapor pelanggaran)

6) Penerapan hukuman mati

7) Iktikad pimpinan 15

Integritas dan kompetensi pejabat publik sangat penting prasyarat untuk administrasi publik yang andal dan efisien. Banyak negara-negara di kawasan dan di luarnya telah mengadopsi langkah-langkah yang bertujuan untuk memastikan integritas dalam mempekerjakan dan mempromosikan staf, berikan yang memadai remunerasi dan menetapkan serta menerapkan aturan perilaku yang jelas untuk publik pejabat.16

Situasi di mana sistem dan prosedur memberikan kesempatan untuk korupsi relatif mudah untuk auditors untuk menangani dan membuat rekomendasi. Namun, auditor dapat menemukan di situ di mana sistem dan prosedurnya memuaskan karena mereka dirancang untuk mencegah atau meminimalkan korupsi. Namun,orang-orang korup mencari tahu cara melewati jalan sistem dan prosedur ini. Itu biasanya dilakukan melalui kolusi. Untuk ujianple, di departemen pekerjaan umum, biasanya ada prosedur rinci untuk memberikan kontrak,menyiapkan bill of quantities, mengawasi kontraktor, mengendalikan dan mengawasing pekerjaan dan kontraktor sertifikasi faktur. Umumnya, prosedur ini memiliki su Kontrol internal internal yang fficient yang bisa mencegah praktik korupsi dan memastikan yang baik kualitas pekerjaan oleh kontraktor. Di berlatih, prosedur ini tidak berfungsi dengan kolusi. Misalnya, semua petugas dari atas ke bawah, yang harus masuk memastikan kualitas dan kepatuhan dengan kontrak,bergandengan tangan. Mereka berbagi "rampasan" dari kontraktor, yang diwajibkan oleh mengurangi kualitas pekerjaan dilakukan, oleh instituti pengaturan onal, di mana semua kertas-pekerjaan dilakukan dengan cara yang rapi. Semua laporan muncul disiapkan dengan tanggal jatuh tempo pada mereka dan semua sertifikat ditandatangani oleh aut yang kompeten. Hanya pekerjaan yang diklaim dimiliki telah dilakukan tidak dalam urutan yang benar. Itu seluruh mesin administrasi yang bertunangan untuk memastikan bahwa pekerjaan itu dari spesifikasi yang tepat bergabung tangan untuk mengalahkan sistem. Dalam situasi seperti itu, apa yang bisa auditor lakukan? Mereka tidak melihat tanda-tanda apa punpeluang korupsi. Dalam situasi seperti itu,audit partisipatif adalah

\footnotetext{
Surachmin. Strategi dan teknik korupsi mengetahui untuk mencegah. Jakarta: Sinar Grafika. 2013. hlm, 91-109. Ibid. hlm, 136-154.

http://www.oecd.org/site/adboecdanti-corruptioninitiative/policyanalysis/35144020.pdf, Diakses Sabtu, 08 Desember 2018 19:25 WIB.
} 
Kosmik Hukum Vol. 20 No. 1 (2020): 45-55

E-ISSN: 2655-9242 | P-ISSN: 1411-9781

DOI: 10.30595/kosmikhukum.v20i1. 3822

jawabannya. Ituauditor harus melibatkan para penggunafasilitas yang dibangun oleh publik bekerja di departemen dalam melakukan audit.17

Para penegak agar dapat menegakkan peraturan perundang-undangan tentang korupsi, para hakim agar memberikan hukuman bagi para koruptor yang setimpal dengan perbuatannya. Perlunya sistem pengawasan oleh lembaga legislatif dan masyarakat terhadap penegakan hukum di Indonesia dan perlu pengawasan sistem oleh Lembaga Komisi Yudisial dalam mengawasi setiap hukum yang diambil oleh hakim dalam memutus perkara tindak pidana korupsi di Indonesia.18

\section{Penutup}

Kondisi korupsi di Indonesia pasca reformasi bukan semakin menurun melainkan meningkat ke segala aspek kehidupan dan disemua bidang penyelenggaraan negara. Korupsi tersebut tidak terjadi secara kebetulan atau seketika, tetapi sudah direncanakan jauh-jauh hari sejak saat perencanaan kerja/kegiatan/penganggarannya dimulai, dan lebih jauh lagi sejak penempatan para pejabat disuatu unit kerja/satuan kerja perangkat daerah maupun lembaga negara, dan tidak terbatas pada saat birokrat dan direksi/komisaris BUMN/BUMD bertugas tetapi juga direncanakan korupsi untuk masa pensiun. Apabila korupsi tersebut dibiarkan terus atau pencegahan dan pemberantasannya berjalan seperti yang dilakukan sekarang, yaitu lamban dan diulur-ulur, penuh dengan diskriminasi, proses peradilan yang penuh permainan mafia, serta sering dijadikan komoditas politik, akibatnya negara Indonesia betul-betul akan hancur karena keuangan negara (rakyat) yang dikorupsi, setiap tahunnya sudah mencapai ratusan triliun rupiah. Penyelenggara negara sudah tidak berwibawa lagi, masyarakat miskin semakin banyak dan semakin sengsara, modal dan kekayaan negara telah berpindah ke tangan asing dan lari keluar negeri, penganguran semakin bertambah hukum sudah tidak ada artinya lagi, yang berakibat merusak sendi-sendi kehidupan masyarakat dan bernegara. Adapun penyebab korupsi yang sedemikian parah dikarenakan antara lain adanya ketimpangan penghasilan sesama pegawai negeri, sifat tamak dan keserahakan, gaya hidup konsumtif, penghasilan yang tidak memadai, tidak adanya keteladanan dari pimpinan, kelemahan sistem pengendalian manajemen, ketutupan organisasi, dukungan budaya negatif dalam masyarakat dan lemahnya penegakan hukum yang penuh dengan nuansa KKN dan diskriminatif. Melihat kondisi tersebut apabila korupsi tidak segera dicegah dan diberantas, tinggal menunggu waktu saja NKRI terjadinya revolusi yang akan menghiasi sejarah kepulauan nusantara yang menandakan bahwa Republik Indonesia pernah ada.

\section{Daftar Pustaka}

Djaja, Ermansyah. Memberantas Korupsi Bersama KPK Kajian Yuridis Normatif UU Nomor 31 Tahun 1999 juncto UU Nomor 20 Tahun 2001 Versi UU Nomor 30 Tahun 2002. Sinar Grafika: Jakarta.

Grace N, Ofoegbu, dan James Isaiah Ekele. 2018. "The Role of Chartered Accountants in Eradicating Corruption in Nigeria", British Journal of Humanities and Social Sciences, April, Vol. 20 No. 1, hlm. 45-50, online pada http://www.ajournal.co.uk/ HSpdfs/HSvolume20(1)/HSVol.20\%20(1)\%20Article\%205.pdf

Khan, Muhammad Akram. 2006. "Role of Audit in Fighting Corruption", makalah dalam pertemuan "Ethics, Integrity, and Accountability in the Public Sector: Re-building Public Trust in Government through the Implementation of the UN Convention against Corruption" 26-27 September 2006 St. Petersburg, Russia.

17 Muhammad Akram Khan, "Role of Audit in Fighting Corruption", makalah dalam pertemuan "Ethics, Integrity, and Accountability in the Public Sector: Re-building Public Trust in Government through the Implementation of the UN Convention against Corruption" 26-27 September 2006 St. Petersburg, Russia.

18 La Sina, " Dampak dan Upaya Pemberantasan Serta Pengawasan Korupsi di Indonesia", Jurnal Pro Justitia, Januari 2008, Volume 26 No. 1, hlm. 35 (33-48) 
Mas, Marwan. 2014. Pemberantasan Tindak Pidana Korupsi, Cet 1. Penerbit Ghalia Indonesia: Bogor.

Sina, La. 2008. "Dampak dan Upaya Pemberantasan Serta Pengawasan Korupsi di Indonesia", Jurnal Pro Justitia, Januari 2008, Volume 26 No. 1, hlm. 33-48

Suwarno, Yogi, dkk. "Strategi Pemberantasan Korupsi", Hasil Penelitian, diakses dari https://www.stialan.ac.id/artikel/artikel\%20yogi.pdf

Surachmin. Strategi dan Teknik Korupsi Mengetahui untuk Mencegah. Sinar Grafika: Jakarta.

Undang-Undang Nomor 31 Tahun 1999 tentang Pemberantasan Tindak Pidana Korupsi.

[...] http://digilib.unila.ac.id/525/7/BAB\%20II.pdf diakses Sabtu, 9 Desember 2018 12:20 WIB.

[...] http://www.oecd.org/site/adboecdanti-

corruptioninitiative/policyanalysis/35144020.pdf, Diakses Sabtu, 08 Desember 2018 19:25 WIB.

[...] http://eprints.walisongo.ac.id/3925/3/104211009_Bab2.pdf Diakses Sabtu, 08 Desember 2018 21:25 WIB.

[...] https://idtesis.com/faktor-penyebab-korupsi/

[...] https://akademik.ugm.ac.id/2017/wpcontent/uploads/2016/12/2013_makalah_kuliah_perdana_pascasarjana_ugm.pdf Diakses Sabtu, 09 Desember 13:17 WIB.

[...] Mulyadi, Dwi Septa. https://edoc.site/jurnal-awan-pdf-free.html Diakses Sabtu, 09 Desember 2018 19:07 WIB.

[...] http://akperrsdustira.ac.id/wp-content/uploads/2017/07/Buku-Pendidikan-AntiKorupsi-untuk-Perguruan-Tinggi-2017-bagian-2-.pdf Diakses Sabtu, 08 Desember 2018 19:20 WIB.

[...] "Research on Corruption A policy oriented survey", http://www.icgg.org/downloads/contribution07_andvig.pdf Diakses, Sabtu 09 Desember 2018 12:49 WIB. 